Published by the UFS

http://journals.ufs.ac.za/index.php/at

(c) Creative Commons With Attribution (CC-BY)

How to cite: Adeleye, B. Popoola, A. Sanni, L. Zitta, N. \& Ayangbile, O. 2019. Poor development control

as flood vulnerability factor in Suleja, Nigeria. Town and Regional planning, no.74, pp. 23-35.

\section{Poor development control as flood vulnerability factor in Suleja, Nigeria}

\section{Bamiji Adeleye, Ayobami Popoola, Lekan Sanni, Nanpon Zitta \& Oluwabukola Ayangbile}

DOI: $h$ ttp://dx.doi.org/10.18820/2415-0495/trp74i1.3

Revised March 2019, Published 30 June 2019

*The authors declared no conflict of interest for this title or article.

\begin{abstract}
Like many developing countries over the decade, Nigeria has experienced rapid urbanization associated with numerous problems such as, among others, improper waste management practices, building development regulations and standards contraventions, environmental pollution, overcrowding, and flooding. In light of the foregoing, this article examines the use and effectiveness of development control measures in addressing flood vulnerability in Suleja, Nigeria. In carrying out this study, buildings vulnerable to flooding were identified and factors influencing their vulnerability as well as the implications of non-adherence to development control measures were also determined. As part of this study, a total of 278 questionnaires were administered to adult residents of the study area, using multi-stage sampling techniques. A quick bird's eye image of 15-meter resolution was used to identify and map out the buildings in the area considered vulnerable to flooding, using a 15-meter setback from the river banks. The study reveals that 799 buildings were built in contravention of building development standards and regulations in Suleja, while indiscriminate solid waste disposal methods were found to be strong factors influencing vulnerability to flooding in the area. The study also revealed that $47 \%$ of drainages in Suleja are blocked with indiscriminately disposed solid waste materials. The study recommends that an improved solid waste management system for Suleja be put in place to stem the imminent outbreak of diseases associated with poor environmental management and that development control measures be strictly enforced by the Niger State Urban Development Board.
\end{abstract}

Keywords: Building standards, development control, flood, solid waste, vulnerability

\section{SWAK ONTWIKKELINGSBEHEERMAATREËLS AS FAKTOR VIR VLOEDPROBLEME IN SULEJA, NIGERIË}

Soos baie ontwikkelende lande, ervaar Nigerië vinnige verstedeliking wat verband hou met baie probleme soos, onder andere, onbehoorlike afvalbestuurspraktyke, bou-ontwikkelingsregulasies en standaarde-oortredings, omgewingsbesoedeling, oorbevolking en oorstromings. In die lig van die voorafgaande, ondersoek hierdie artikel die gebruik en doeltreffendheid van ontwikkelingsbeheermaatreëls in die aanspreek van vloedprobleme in Suleja, Nigerië. By die uitvoering van hierdie studie is geboue wat kwesbaar is vir oorstroming geïdentifiseer, en faktore wat hul kwesbaarheid beïnvloed, sowel as die implikasies van nie-nakoming van ontwikkelingsbeheermaatreëls is ook bepaal. As deel van hierdie studie is altesaam 278 vraelyste aan volwasse inwoners van die studiegebied versprei deur gebruik te maak van meervoudige monsternemingstegnieke. 'n Vinnige voëlagtige beeld van 'n resolusie van 15 meter is gebruik om die geboue in die gebied wat kwesbaar is vir oorstromings, te identifiseer en uit te kaart, met 'n 15-meter terugslag van dierivieroewers. Die studie toon dat 799 geboue teenstrydig is met bou-ontwikkelingsstandaarde en -regulasies in Suleja, terwyl onoordeelkundige vaste afvalmetodes sterk faktore is wat die kwesbaarheid van oorstromings in die gebied beïnvloed. Die studie het ook onthul dat $47 \%$ van die dreinering in Suleja met onoordeelkundig beskikbare vaste afvalstowwe geblokkeer word. Die studie beveel aan dat 'n verbeterde vaste afvalbestuurstelsel vir Suleja die uitbreek van siektes wat met swak omgewingsbestuur geassosieer word, sal stuit en dat die ontwikkelingsbeheermaatreëls streng deur die Nigerse Stedelike Ontwikkelingsraad toegepas moet word.

Sleutelwoorde: Boustandaarde, kwesbaarheid, ontwikkelingsbeheer, vaste afval, vloed

\section{TAOLO YA BOEMO BO TLASE YA NTSHETSOPELE JWALO KA NTLHA YA KGONAHALO E BOBEBE YA DIKGOHOLA SULEJA, NIGERIA}

Jwalo ka dinaheng tse ngata tse tlasa ntshetsopele dilemong tse fetang tse leshome, Nigeria e bile le kgolo e potlakileng, e amahantsweng le mathata a mmalwa; jwalo ka mekgwa ya taolo e seng hantle ya dithwele, ditlolo tsa melawana le dipehelo tsa ntshetsopele ya moaho, tshilafatso ya tikoloho, bongata bo boholo ba batho le dikgohola. Ka lebaka la tse

Mr Bamiji Michael (B.M.) Adeleye, Lecturer II, Department of Urban and Regional Planning, Federal University of Technology, Minna, P.M.B. 65 Minna, Niger State. Phone: +2348053131261, e-mail: <banji.adeleye@futminna.edu.ng> DOI: https://orcid.org/0000-0001-7442-5683

Mr Ayobami Abayomi (A.A.) Popoola, Research Student, Department of Town and Regional Planning, KwaZulu-Natal University, Durban, 51 Myro Drive, Glenmore, Durban, South Africa 4001. Phone: +27 728 430285, e-mail: <bcoolay2@yahoo.com>

Dr Lekan Mohammed (L.M.) Sanni, Senior Lecturer, Department of Urban and Regional Planning, Federal University of Technology, Minna, P.M.B. 65 Minna, Niger State. Phone: +2348038404796, e-mail: <sanni.lekan@futminna.edu.ng> DOI: https://orcid.org/0000-0001-8090-0997

Mr Nanpon (N.) Zitta, Lecturer II, Department of Surveying and Geo-Informatics, Federal University of Technology, Minna, P.M.B. 65 Minna, Niger State. Phone: +2347030061896, e-mail: <zitta.nanpon@futminna.edu.ng> DOI: https://orcid.org/0000-0001-5964-655X

Mrs Oluwabukola Adetola (O.A.) Ayangbile, Research Student, Department of Urban and Regional Planning, University of Ibadan, P.M.B 5116 Ibadan, Oyo State, Nigeria. Phone: +2348050288595, e-mail:<bukiayangbile@yahoo.com> 
qetang ho bolelwa, atikele ena e hlahoba tshebediso le katleho ya mekgwa ya taolo ya ntshetsopele bakeng sa ho tobana le kgonahalo e bobebe ya dikgohola Suleja, Nigeria. Ho ntshetsa thuto ena pele, meaho e ka angwang ha bobebe ke dikgohola e ile ya qoollwa le dintlha tse nang le kgahlamelo kamehong ya tsona e bobebe, hammoho le ditlamorao tsa ho se ikamahanye le ho se hlomphe mekgwa ya taolo ya ntshetsopele; di ile tsa bewa. Jwalo ka karolo ya thuto ena, manane a dipotso a 278 ka kakaretso a ile a fuwa baahi ba seng ba hodile karolong eo ya thuto, ho sebediswa mekgwa ya sampole e nang le dikarolo tse ngata (multi sampling techniques). Senepe se nkuweng ka potlako ke motho ya leng hodimo dikilomitareng tse 15 se sebedisitswe jwalo ka tharollo ho bontsha le ho qoolla meaho e ka angwang habebe ke dikgohola sebakeng seo, ho sebediswa kgoreletso (setback) ya dimetara tse 15 ho tloha mabopong a noka. Thuto ena e hlahisa hore meaho e 799 e ne e ahilwe kgahlanong le melawana ya maemo a ntshetsopele Suleja, ka nako yona eo mekgwa ya ho phutha matlakala ntle le ho a kgetha, e fumanwe e le mabaka a maholo a nang le kgahlamelo bakeng sa kgonahalo e bobebe ya dikgohola sebakeng seo. Thuto ena e utollotse hore $47 \%$ ya diforo Suleja e thibilwe ke disebediswa tsa matlaka a thata a lahlilweng. Thuto ena e eletsa hore mokgwa o ntlafaditsweng wa taolo ya matlakala a thata e sebediswe bakeng sa Suleja ho thiba ho qhoma ho ka etsahalang hwa mafu a amahanngwang le taolo ya maemo a tlase ya tikoloho le hore mekgwa ya taolo ya ntshetsopele e etsahatswe ka thata ke Niger State Urban Development Board.

\section{INTRODUCTION}

The alarming pace of rapid urbanization experienced in many developing countries, including Nigeria, is often accompanied by numerous challenges (Olotuah \& Adesiji, 2005; Adetunji \& Oyeleye, 2013; Lekwot, Kyom \& Balasom, 2013: 48; Oyeleye, 2013), especially in cities with less regard for urban planning. These challenges include severe housing shortages and proliferation of improperly constructed housing structures and informal settlements, poor environmental management and sanitation practices, dearth of critical infrastructures, rising crime rates, and flooding (Kadi, Halingali \& Ravishankar, 2012;
Okorie, 2015; Junaid, 2017). Of these problems, the incidence of flooding has become perennial in many cities in the developing countries where several lives and property worth several millions of US Dollars are lost annually in addition to the dislocation of several socioeconomic activities (Nelson, 2001; ActionAid, 2006; UN-Water, 2011). In Nigeria, many of the state capitals and cities are perennially dealing with many of these problems, particularly the menace of poor waste management practices and flooding (Potschin, 2009; Satterthwaite, Huq, Pelling, Reid \& Romero Lankao, 2007), problems that seemed to have defiled many of the solutions adopted over the years (Nkwunonwo, 2016). Although urban flooding in Nigeria has been attributed to several causal factors, including climate change-induced heavy rainfall, indiscriminate waste dumping and erection of structures along floodplains are increasingly being cited as bigger challenges (Satterthwaite et al., 2007; Potschin, 2009; Odufuwa, Adedeji, Oladesu \& Bongwa, 2012; Agbonkhese, O., Agbonkhese, E.G, Aka, Joe-Abaya, Ocholi \& Adekunle, 2014).

In July 2017, Suleja, an urban settlement bordering Abuja, Nigeria's federal capital city, was wrecked by a devastating flood which killed 18 persons, destroyed properties, and left residents homeless (Opara, 2017: online). Some building experts and urban planners contended that the perennial flooding experienced in Suleja was man-made and can directly be linked to the poor application of development control measures in the settlement (Bwala, Oladosu \& Nghalmi, 2016; Onwubiko, 2017).

Various studies (Obabori, Obiuwevbi \& Olomu, 2007; Aluko, 2011; Ogundele, Ayo,Odewumi \& Aigbe, 2011; Lekwot et al., 2013) have been carried out on development control, with emphasis on building contravention, building codes, building standard, and zoning, thus neglecting the application of development control measures in tackling impending flood disasters. The limited studies on the application of development control measures in addressing disasters have enmeshed urban planners and policymakers in a difficult situation in finding a lasting solution to the problems emanating from the incessant flood experienced in the urban centres in Nigeria. It is against the foregoing that this study seeks to examine development control as a strategy for addressing or preventing urban flooding in Suleja, Nigeria. Among others, the study examined the pattern of building development, particularly along the floodplains in the city, the level of compliance with building codes and regulations in building development, and other environment-related factors that are responsible for flooding in Suleja.

\section{LITERATURE REVIEW}

In order to understand the implication of development control in Suleja, Nigeria, it is important to introduce the current theory on urban flooding included in this study. The existing theory focuses on development control; urban resilience to floods; flooding and flood vulnerability; poor development control measures, and urban flood vulnerability.

\subsection{Development control}

Development control, in the context of urban planning, is the process of implementing building and land subdivision regulations and specifications to regulate land use and physical development of land (Yemi, 2004). Development control in this regard is a professional activity carried out by town planners, planning authorities and physical planning agencies in order to ensure compliance with the approved master plan (Ola, 2011: 169). It is viewed as a mechanism and measure put in place to maintain standards and to guide orderly urban development (Lekwot et al., 2013: 49; Ahmed \& Dinye, 2011: 210; Obabori et al., 2007). Development control affects the general public most, as it ensures an orderly 
growth of settlements by stipulating adequate standards for all aspects of land use through the provision of adequate lighting, ventilation, open spaces, and other sociocultural facilities that make life worth living (Ogunsesan, 2004: 51). Development control positively encourages developers to focus on the protection and enhancement of the built environment; the coordination of both public and private investments in land and property to ensure that land is efficiently used, and the control of pollution (Lekwot et al., 2013: 50; Ogunsesan, 2004: 50).

The 1917 Township Ordinance, 1928 Lagos Town Planning Ordinance, Nigeria Town and Country Planning Act of 1946, and the 1954 Federal Constitution were all intended to maintain spatial orderliness and sanitation in urban land-use activities (Kio-Lawson, Duru, John \& Eebee, 2016: 148). To ensure a more effective measure to control development, the 1992 Nigerian Urban and Regional Planning Decree was established, in which 47 sections confer power on the federal, state and local government council to establish planning authorities and prepare a physical development planning scheme at each level (FGN, 1992; Omole, 2012; Kio-Lawson et al., 2016: 148).

Following this, the state and local council established several planning authorities in different states to regulate physical development. Despite the existence of these physical planning agencies, the majority of the Nigerian cities, including Suleja, still show evidence of environmental decay, incompatible physical development, increasing status of slums, and flooding in some cities in the country (Kio-Lawson et al., 2016: 148).

\subsection{Urban resilience to floods}

The theory of urban resilience was first used by Crawford Holling in 1973 to define the resilience of an ecosystem as the measure of its ability to absorb changes and still persist (McAslan, 2010). Urban resilience to floods is defined as the capacity of the city to tolerate flooding and to reorganize, should physical damage and socioeconomic disruption occur, so as to prevent deaths and injuries and maintain the current socioeconomic identity (Adger, 2000: 347; Gunderson, 2010: 18; Meerow, Newell \& Stults, 2016: 38). Urban resilience to floods is measured by a city's physical ability to accommodate - not resist - flooding (Walker \& Westley, 2011: 4; Liao, 2012: 48). This means that a city takes the necessary precautions to prevent flooding, but also adapts land use to suffer less in case of a flood disaster (Woltjer \& Van den Brink, 2015: 45). According to Liao (2012: 48), these precautions form the key properties of urban resilience to floods and include, among others, the localized flood-response capacity of cities; timely adjustments after every flood, and the redundancy in subsystems, which means that the flood-response capacity would be distributed across the levels (i.e., individuals, communities, and the municipality) such that when the capacity of one level is overwhelmed, the city can still count on the others (Walker, Holling, Carpenter \& Kinzig, 2004: 5; Adger, 2006: 347; Davoudi, 2012: 203).

The application of the urban resilience theory to this study would help the populace and stakeholders in being proactive in the area of preparing strategic operational plans and programmes that address retrofitting the built environment and adding redundancy, diversity, and flexibility into every subsystem. This means that open spaces can convey and store floodwater during wet seasons (Douglas, Kobold, Lawson, Pasche \& White, 2007: 29); buildings can be remodelled to be elevated, floatable, or wet-proofed (Guikema, 2009: 1302), and infrastructure can be redesigned into a collection of diverse functional elements that are flexible in operation (Liao, 2012). The immediate real-world challenge is that urban resilience towards floods is always a work in progress and requires the capacity to create a fundamentally new resilience system (Liao, 2012). Once the theory of urban resilience is understood, the concept of awareness, detection and avoidance would help sensitize the populace on the need to discourage building along waterways and indiscriminate solid waste disposals, most especially in drainages in the study area.

\subsection{Flooding and flood vulnerability}

Flooding has been defined in a variety of ways depending on the causal factors, type, magnitude and place of occurrence. It is, however, generally described as an unusual stage or rise of water in a stream channel, resulting in the stream overflowing its banks (Odunuga, Oyebande \& Omojola, 2012). It is the inundation of an area, not usually covered by water, with a large flow of water as a result of a temporary rise in stream, river, lake, or sea level (Agbonkhese et al., 2014). When large pools of water overrun streets and neighbourhoods in an urban area, usually as a result of heavy rainfall, it is described as urban flooding. Urban flooding is also described as a condition in which urban drainage channels overflow into the streets and surrounding areas and homes, usually as a result of severe rainfall over a short period of time (Odunuga et al., 2012). In many respects, urban flooding is viewed as hazardous and sometimes disastrous, as it destroys housing structures, damages drainage channels, causes disruption of social and economic activities, and sometimes results in the deaths of some residents of affected areas (ActionAid, 2006; Gwary, 2008). Many urban residents in many cities across the world, particularly in the developing countries, are not only vulnerable to flooding but also have been victims. When flooding occurs in the city, it results in the disruption of the normal functioning of socio-economic activities, pollution and sanitary challenges, among others (Chen, 2004).

Most of the victims of urban flooding in the developing countries are the 
poor and marginalized, particularly those living on marginal land, floodplains or improperly planned and developed neighbourhoods (Blaikie, Cannon, Davis \& Wisner, 1994; Odufuwa et al., 2012). While many may be vulnerable, some, especially those residing in better planned and developed neighbourhoods of the cities, are usually not affected, particularly where the flooding is described as a flash flood. Pelling (1997) viewed vulnerability as a concept that is a function of exposure to some identifiable risks (location relative to hazard). Varieties of vulnerability have been identified and include individual, social, economic, ecological and urban, among others (Luers, Lobell, Sklar, Addams \& Matson, 2003; Adger, 2006: 269). The common baseline is that vulnerability of whatever form is dependent on the existence and exposure to some form of risk or harm as a consequence of some external shock (Muller, Reiter \& Weiland, 2017).

With regard to flooding, vulnerability is described as resulting from the social and physical conditions that make parts of an urban system susceptible to experience damage from an after-flood event (modified by Wisner, Blaikie, Cannon \& Davis, 2004; Muller et al., 2017). This implies that particular neighbourhoods of the cities, by their physical and social circumstances (exposure factors), are vulnerable to flooding. In many instances of urban flooding, the elements commonly at risk are usually the poorest segment of the population, improperly or poorly built housing and civil engineering structures, and public infrastructures (United Nations International Strategy for Disaster Reduction, 2015: online). It is, therefore, essential to emphasize that no proper or effective flood control measures can be emplaced without first identifying elements that are vulnerable and the causes of their vulnerability.

\subsection{Poor development control measures and urban flood vulnerability}

Many cities in the developing countries are vulnerable to flooding, due to poor development control measures that result in unguided physical planning, and neglect or poor observance of planning laws and land-use regulations as part of the larger ineffective urban planning

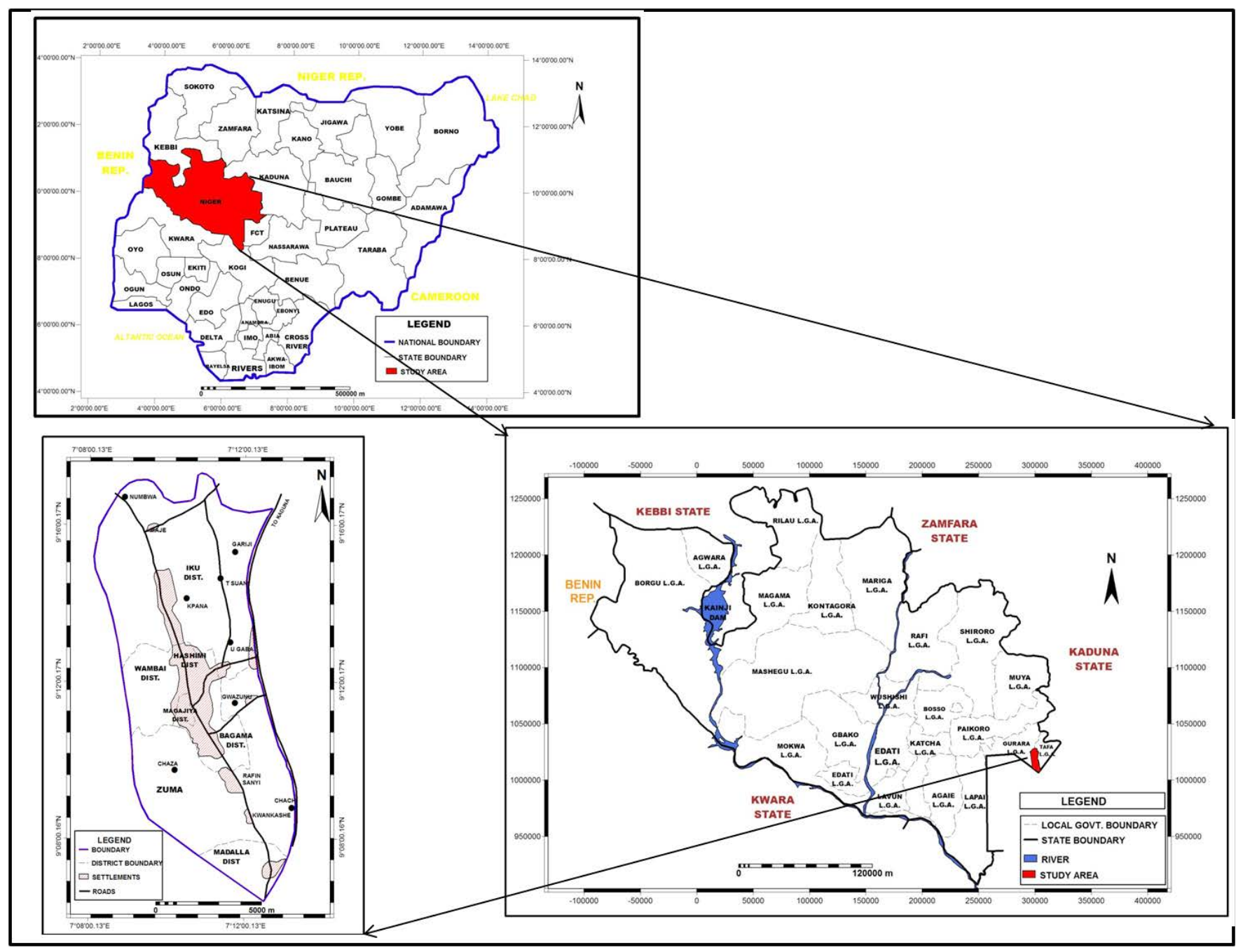

Figure 1: Administrative map of Nigeria highlighting the study area

Source: $\quad$ Department of Urban and Regional Planning, Federal University of Technology, Minna, 2015 
structure. A sizeable number of African countries have recorded a long repetitious list of failures in efforts at regulating urban space because of the ineffectiveness of development control measures (Mabogunje, 1990 in Goodfellow, 2013). In Nigeria, constant political interference, the lack of political will by the government in enforcing planning laws, the entrenched corrupt practices among urban planning officials, especially site inspectors, poor working environment, and the absence of relevant facilities have failed the physical development control measures and system (Aluko, 2011).

According to Goodfellow (2013), the weaknesses of, and the laxity in the implementation of development control measures have led to problems such as rapid urbanisation, uncontrolled urban growth, unregulated informal settlements on the low-lying floodplain areas, littering of the environment with uncollected solid waste, and poor maintenance of drainage. Together with incessant flooding experienced in various cities in Nigeria, these are major contributors to urban flood vulnerability (Douglas, Alam, Maghenda, Mcdonnell, McLean \& Campbell, 2008: 187; Eguaroje, Alaga, Ogbole, Omolere, Alwadood, Kolawole et al., 2015: 149).

To mitigate the incidence of flooding and urban flood vulnerability, Nigerian cities should employ flood-risk vulnerability assessments (Salami, von Meding \& Giggins, 2017: 370). According to Marrickville Council (2015) and Ashfield Council (2015), the primary method of flood-risk vulnerability assessment is through the application of development control measures. Using this application will help minimise damage to properties and risk to life, and ensure that existing flood-prone areas would not be adversely affected by vulnerability to flooding (Marrickville Council, 2015; Bwala et al., 2016).

\section{STUDY AREA}

Suleja Local Government Area in Niger State, Nigeria (Figure 1), lies between latitudes 9 $9^{\circ}$ '13.8' and 9'17'49.35" north of the Equator and longitude 7०6'58.6' and 7012'18.41' east of Greenwich Meridian. Suleja Local Government Area has a population of 216578 with 10 political wards (NPC, 2006). The strategic location of Suleja has had the most profound effect on its development and its potential growth in the near future. It is a rapidly growing medium-sized city whose growth was in part attributed to its closeness to Abuja, the nation's capital city, with a distance of approximately 70 kilometres (see Figure 1).

As one of the closest urban settlements bordering Abuja, Suleja has provided residency to many of the low-income workers and informal sector employees who work in Abuja, but could not afford the exorbitant rent of housing charged in almost all parts of the city. As a result, Suleja has become some kind of sanctuary to this large number of low-income groups and has continuously witnessed massive inward population movement and expansion over the past couple of decades. The desire to meet the shelter needs of this group of people, among other factors, has led to the development of all forms of housing structures and sometimes on marginal lands, many of which are built without due regard to extant building development regulations and standards in the country (UN-Habitat, 2003).

In July 2017, Suleja was wrecked by a devastating flood, in which 18 persons were killed and properties worth several millions of Naira were destroyed. Several hundred other residents were rendered homeless by the devastating flood which was attributed in part to the blockage of drainages by solid waste and the erection of buildings along waterways (Warami, 2017). Several building experts contended that the obstructions of drainage channels by solid waste will always keep the floodplain soil saturated with water and buildings erected along these channels would, therefore, become vulnerable to flooding at the slightest rise in water-flow rates
(Bwala et al., 2015). Contrary to this claim, urban planners were of the view that the perennial flooding experienced in Suleja, as in many other urban centres in Nigeria, was man-made and can be linked to the deficiencies in the implementation and enforcement of the 1992 Nigeria Urban and Regional Planning Law (Onwubiko, 2017), which copiously made provisions for development control. It is further contended that, where the various development control instruments are effectively deployed such that building codes and regulations are strictly enforced and unwholesome physical developments are prevented as a result, the incidence of flooding as experienced perennially in Suleja could have been prevented.

Part Two, subsection 31(a) of the 1992 Nigerian Urban and Regional Planning Law (FGN, 1992) recommended that development should be rejected if not in accordance with an approved plan, while Part Two, subsection 31(e) stipulated that any building that constitutes a nuisance to the inhabitants of the community or contains such additional facilities that are not in the estimation of the physical development plan for the community should not be approved by the planning authorities. Section 61(1) also states that the development control department shall have the power to serve a 'demolition notice' on a developer, if a structure erected by the developer is found to be defective as to pose danger or constitute a nuisance to the complainer and the public. These provisions indicate that, when development control tools are strictly enforced by planning authorities, buildings will not be erected on marginal land portions or sites along waterways.

\section{RESEARCH METHODOLOGY}

The study used a mixed methods design, in which qualitative and quantitative data are collected in parallel, analysed separately, and then merged (Creswell, 2014). In 
this study, official documents from planning authorities on development control standards/measures as well as development permits were used to examine the non-adherence of development control measures in Suleja. Satellite imagery was used to examine flood vulnerability of the buildings and those that contravened development control measures.

A field study was conducted in all the 10 political wards in Suleja. In the course of the field study, photographs were taken and ground "truthing" of the features that appeared vague on the satellite imagery were reconciled with the actual features on the ground. The questionnaire survey explored factors influencing flood vulnerability and the factors influencing the non-adherence of development control measures as well as the effects of non-adherence to development control measure from residents in Suleja. The reason for collecting both quantitative and qualitative data is to elaborate on specific findings from the breakdown of the official documents such as similar factors influencing flood vulnerability suggested from respondents (Creswell, 2014; Creswell \& Plano-Clark, 2007).

\subsection{Sample size and sampling procedure}

A sample size of 278 from the total number of projected 273735 residents representing $0.1 \%$ was selected for the questionnaire survey. One of the basic principles guiding the selection of sample size is that the smaller the population, the bigger the sampling ratio has to be for an accurate sample. Neuman (1991) is of the opinion that a larger population size allows for a smaller sample size ratio for equal sampling. In selecting the sample, a multi-stage sampling technique was adopted such that each member of the population had an equal chance of being sampled. For the purpose of sampling, the study area was first alienated into 10 geographical entities, based on the 10 political wards in the study area (see Table 1), followed by the neighbourhood delineation of the political wards. From this, 44 nonoverlapping neighbourhoods were identified and the major streets in the neighbourhoods were identified at the third stage. The final stage of the sampling process was the random selection of $0.1 \%$ of the residents (many of whom were adults) from the classified wards with all neighbourhood streets represented in the sample.

\subsection{Data collection}

Using open data kits (ODK), a questionnaire survey was administered to 278 selected residents from 10 wards in Suleja, Nigeria, from 25 September to 7 October 2017. ODK allows the collection of data offline and submit the data, when internet connectivity is available (Hartung, Lerer, Anokwa, Tseng, Brunette \& Borriello, 2010: article 18). Topics on

Table 1: Sample frame and sample size

\begin{tabular}{|c|l|c|c|c|c|}
\hline S/N & Wards & $\begin{array}{c}\text { No. of } \\
\text { neighbourhoods }\end{array}$ & No. of streets & Sample frame & $\begin{array}{c}\text { Sample size } \\
\mathbf{( 0 . 1 \% )}\end{array}$ \\
\hline 1 & Bagama "A" & 5 & 27 & 26602 & 27 \\
\hline 2 & Bagama "B" & 4 & 25 & 24710 & 25 \\
\hline 3 & Magajiya & 4 & 26 & 25780 & 26 \\
\hline 4 & Iku South I & 5 & 30 & 30181 & 30 \\
\hline 5 & Iku South II & 5 & 32 & 31757 & 32 \\
\hline 6 & Hashimi A & 3 & 24 & 23709 & 24 \\
\hline 7 & Hashimi B & 4 & 29 & 28892 & 29 \\
\hline 8 & KurminSarki & 5 & 31 & 27036 & 27 \\
\hline 9 & Maje & 4 & 27 & 28601 & 27 \\
\hline 10 & Wambai & 5 & 27 & 31467 & 31 \\
\hline Total & & 44 & 278 & 278735 & 278 \\
\hline
\end{tabular}

Source: Authors' field survey

flood vulnerability used in the survey were extracted from reviews of the literature. In the survey, respondents were asked to indicate their choice of factors influencing flood vulnerability and the factors influencing the non-adherence of development control measures in Suleja as well as the effects of non-adherence to development control measure by means of the check-box method.

A breakdown of official documents on development control standards/ measures as well as development permits were used to examine the non-adherence of development control measures in Suleja. Official documents on development control standards/measures, particularly those relating to setbacks for rivers and canals, were obtained from the planning permit platform of Nigeria. Documents relating to application and issuance of development permits were obtained from the Niger State Urban Development Board (NSUDB), Suleja Zonal Office. The information extracted from the documents included general information on building plans, the physical development master plan, and non-compliance of development control measures.

To determine the buildings vulnerable to flooding and those that contravened development control measures, high resolution satellite images ("quick bird") of 15-meter resolution were acquired by means of the "terra incognita" application, a program for downloading web source maps or local files maps for various programs or GPS devices (Sourceforge, 2019: online).

\subsection{Data analysis}

Responses on flood vulnerability gathered through the open data kits were downloaded in Microsoft Excel $®$ (Microsoft Office $\circledR$ suite 2007), and these data were imported into JASP 0.8.0.0 software. Responses were tabulated and descriptive statistics was used to analyse the data on factors influencing flood vulnerability and factors influencing the non-adherence of development control measures in Suleja, as well 
as the effects of non-adherence to development control measures (Bhattacharyya \& Johnson, 2014). This technique summarises data in an understandable way, by using frequencies and percentages (numerical) to reduce the number of responses to a mean score (Satake, 2016: 663).

On the satellite images acquired, a buffer (setback) of 15 meters, as approved by the Niger State Urban Development Board (NSUDB) for riverside areas, was created along the water channels in the study area. This task was performed using the analysis tool in the Arc toolbox of ArcGIS 10.2 software. Buildings that fall within the buffer line were also digitized on ArcGIS 10.2 and their actual numbers were determined on the attribute table created for the buildings. The Digital Terrain Model of Suleja was produced by interpolating the contours of the study area; hence, a vulnerability map was produced for the study area.

Data gathered through the breakdown of official documents included the number of building plans submitted for approval, the percentage of building plans approved, population data and volume of solid waste collected yearly. These data were analysed using simple descriptive statistics of frequency and percentage.

\section{RESULTS AND DISCUSSION}

\subsection{Flood vulnerability in Suleja}

To determine the buildings vulnerable to flooding in Suleja, a buffer/set back of 15 meters, as stipulated by the local planning authority in Suleja (Niger State Urban Development
Board), was created along the river channels. Buildings that fell within the buffer zones were mapped and considered to have contravened the development standards and as such vulnerable to flooding. The analysis revealed that a total of 799 buildings in the study area were developed in contravention of the development control standards. The contravening buildings, according to section 61(1) of the Nigerian Urban and Regional Planning Law of 1992 ought to have been demolished, because they pose a threat to the occupants and the public at large. The vulnerable/ contravening buildings are represented in red in Figure 2.

The high number of buildings developed in contravention of extant building regulations standards in the study area was attributed to laxity in enforcing development control measures by the town planning

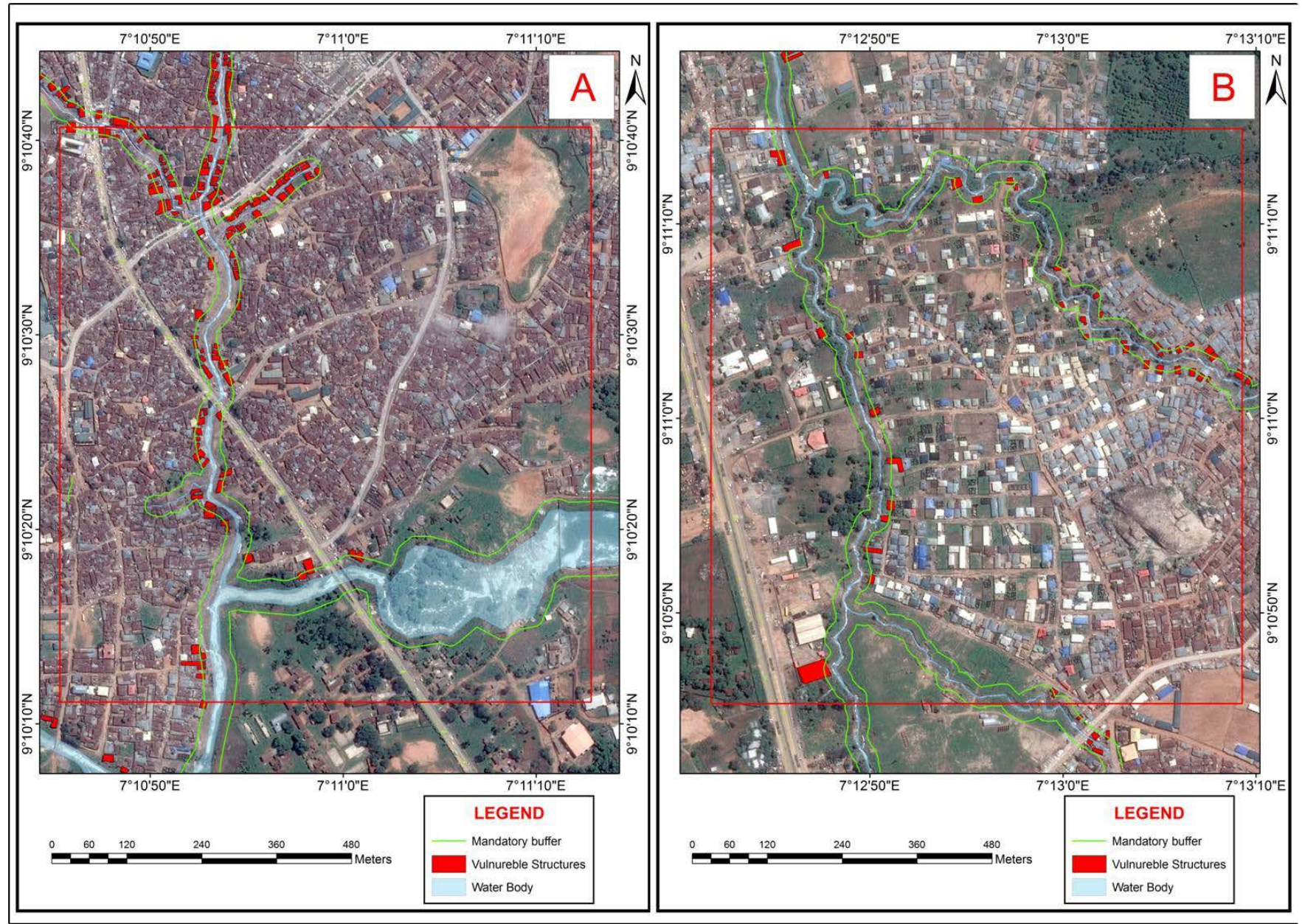

Figure 2: A section of the vulnerable/contravening buildings in Suleja

Source: Authors' field survey 
officers as well as the bureaucratic bottlenecks involved in the building approval process by the Niger State Urban Development Board. According to the Board (NSUDB), only 35\% of the building plans submitted for approval were approved annually. Between 1987 and 2015, out of the 2656 plans submitted, only 932 building plans were approved by the Board (NSUDB) (Adeleye, 2015). The refusal of the Board (NSUDB) to approve not more than $35 \%$ of the plans submitted forced developers to proceed with their building development, regardless of the obvious implications of such acts, including vulnerability to flooding. This act of disregard for development control regulations gave rise to the development of buildings on marginal land portions and flood-prone areas. To produce a vulnerability map, a digital elevation model and the contour map with the rivers (water bodies) of Suleja were overlaid. The analysis from the digital elevation model reveals that the elevation of Suleja ranges from 274 to 528 above sea level (Figure 3).

Figure 4 shows a section of the vulnerability map of Suleja. The areas of the study considered vulnerable to flooding were thus classified into three, based on their relative proximity to the river channels: low flood-risk areas, moderate flood-risk areas, and high flood-risk areas.

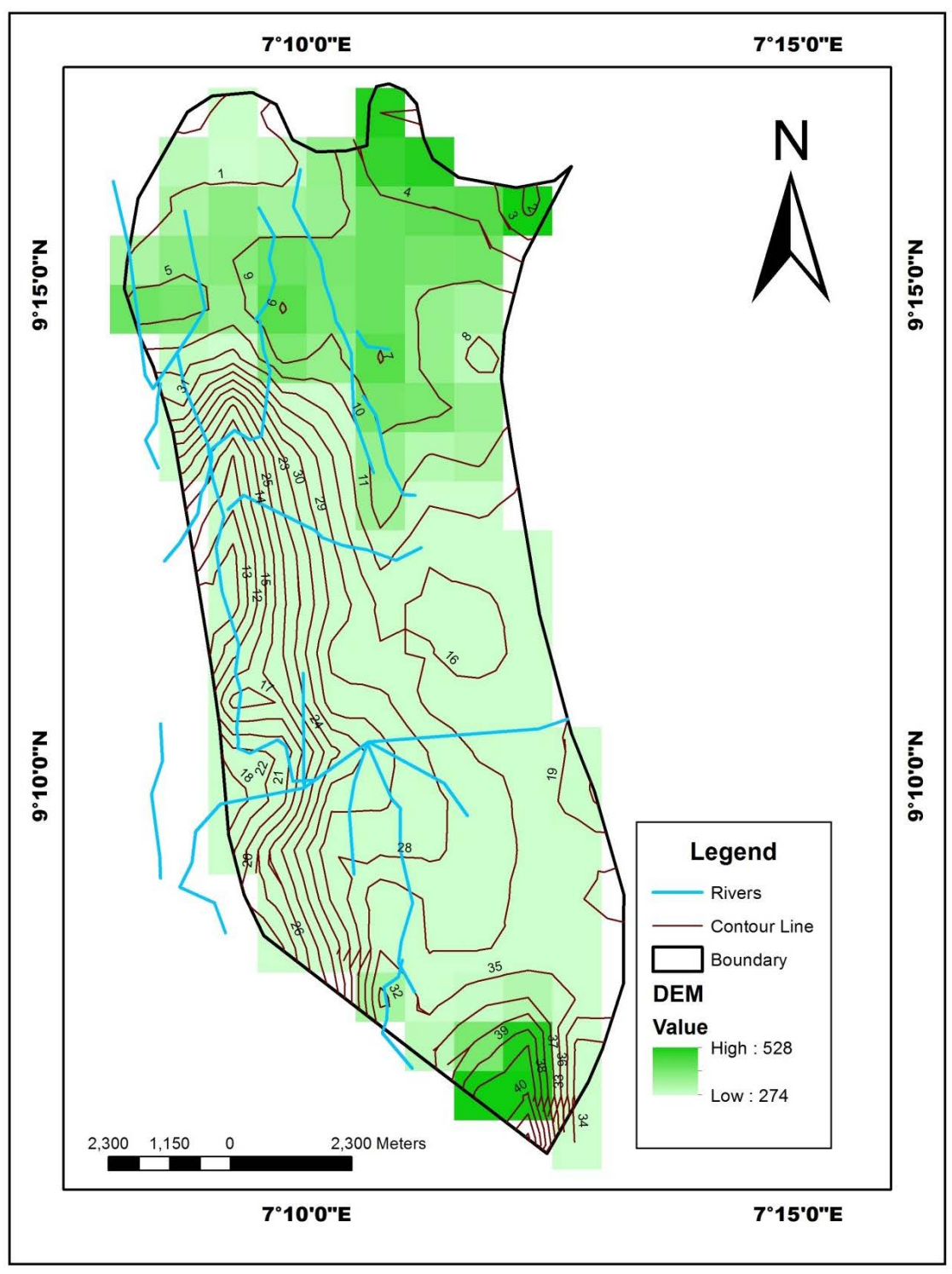

Figure 3: DEM and contour map of Suleja

Source: Authors' field survey
Low flood-risk areas are those with a possibility of less than $3 \%$ chance of flood vulnerability, while the moderate flood-risk and high flood-risk areas have a possibility of $50 \%-90 \%$ and more than $90 \%$ chance of flood vulnerability, respectively.

\subsection{Factors influencing flood vulnerability in Suleja}

In 1976, the Federal Government's decision to move the federal capital territory from Lagos to Abuja had a significant impact on the growth of Suleja, a sub-hub of the new Federal Capital Territory. Following this proclamation, the first master plan was prepared for Suleja in 1987, in order to guide and control the increasing physical development. According to the Niger State Urban Development Board (NSUDB), the Suleja master plan expired in 1997 and is yet to be reviewed. The inability of the Niger State Government to review the master plan in 1997 is momentous to present physical development challenges faced in Suleja. Table 2 shows that, since the master plan was prepared in 1987, Suleja has recorded a significant increase in population growth. Table 2 reveals that the population of Suleja increased from 53960 in 1987 to 316067 in 2018, with 485\% increase. The implication of the population explosion and the obsolete master plan is the chaotic physical development evident in Suleja.

Table 2: Population of Suleja between 1987 and 2018

\begin{tabular}{|r|r|r|}
\hline Year & Population & $\begin{array}{r}\text { Percentage of increase } \\
\text { (\%) }\end{array}$ \\
\hline 1987 & 53960 & \\
\hline 2018 & 316064 & 485 \\
\hline
\end{tabular}

Source: Projected with a growth rate of $3.2 \%$ from National Population Commission, 2006.

Poor compliance with building regulations in the study area, indiscriminate waste disposal methods, especially on waterways, poor drainage system, building on marginal land portions, and building along the river banks were other factors generally 


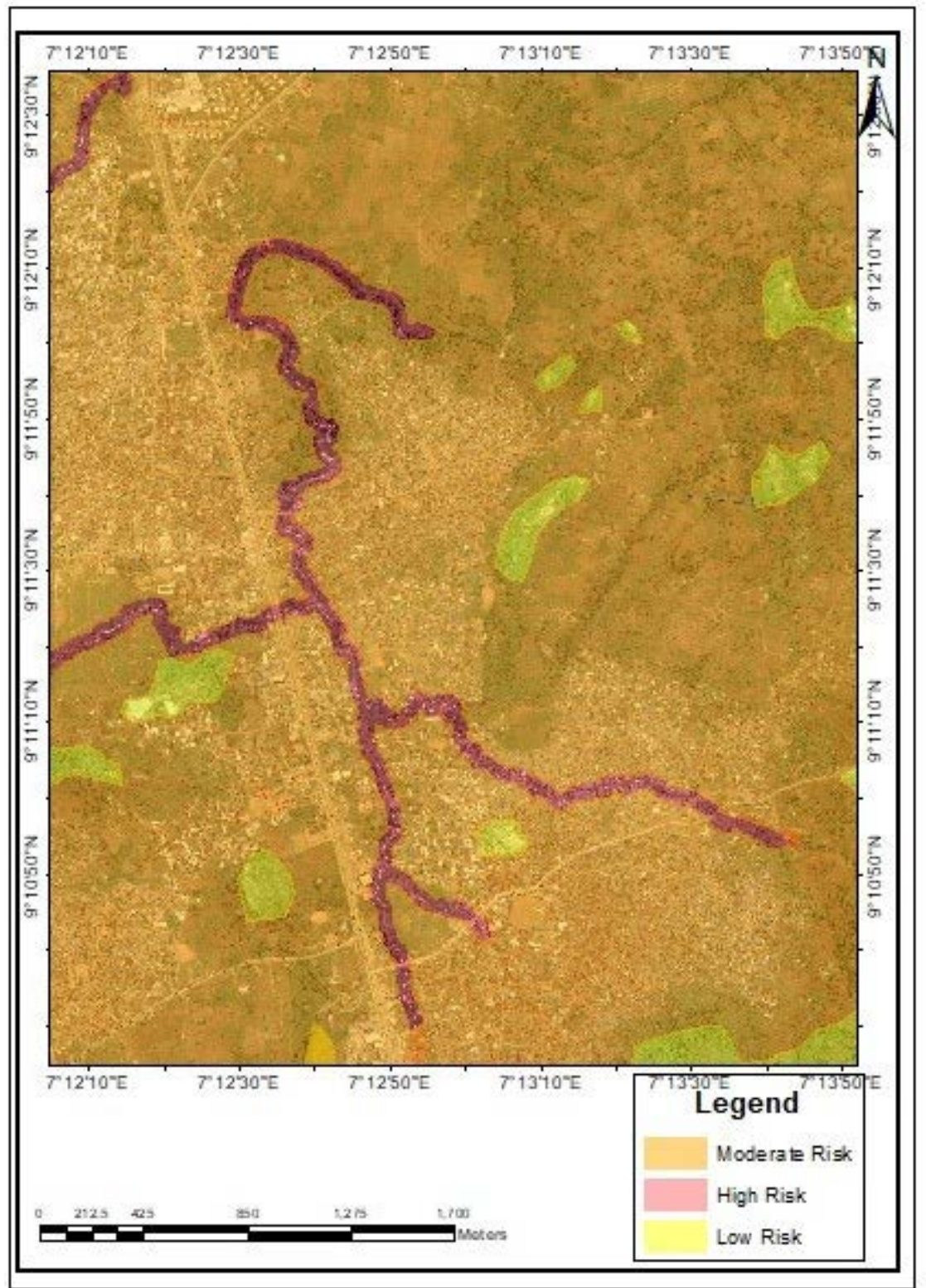

Figure 4: A section of the vulnerability map of Suleja

Source: Authors' field survey

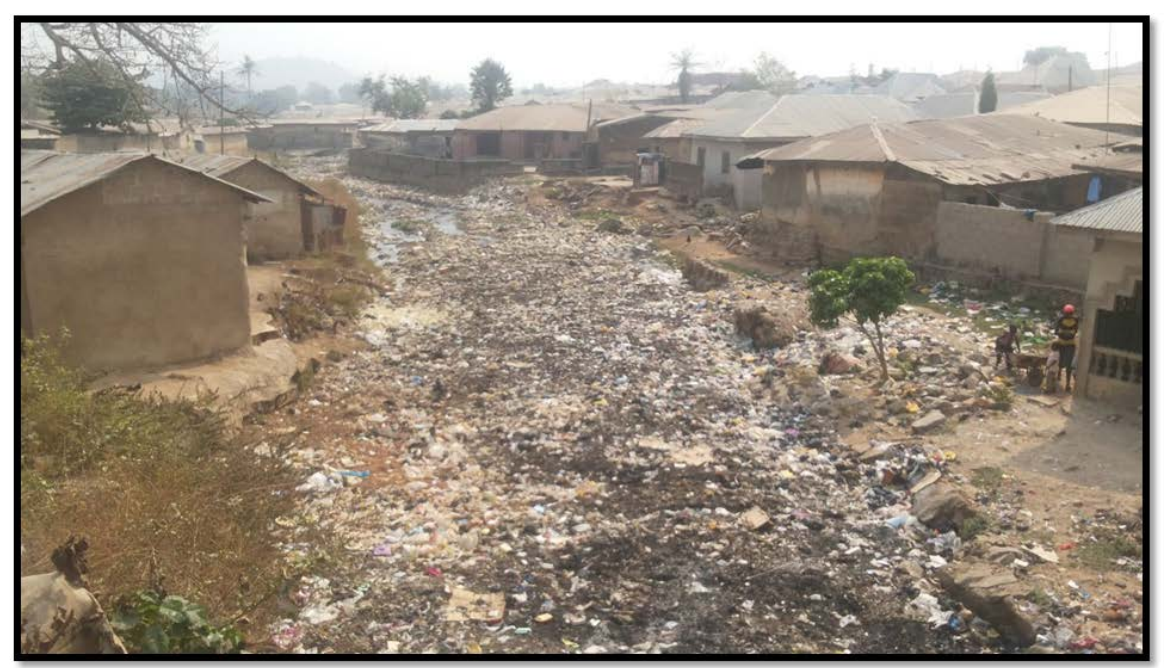

Image 1: Water channel filled with solid waste in Suleja

Source: Authors' field survey considered to be responsible for flood vulnerability in the study area. Table 3 reveals that $43.5 \%$ of the respondents were of the view that indiscriminate waste disposal is a strong factor, while $18 \%$ were of the view that flood vulnerability in the area is also influenced by the poor drainage system. This claim was corroborated by the field survey carried out in the area.

During the field survey, it was observed that uncollected solid waste littered many of the streets and water channels in Suleja (see Image 1). It was said that, since 2013, the Niger State Environmental Protection Agency collected an annual average total of 308940 cubic meters of solid waste in Suleja. It should, however, be stated that this statistic did not seem to reflect the true picture of solid waste collection in the area, as large volumes of solid waste were left uncollected daily in Suleja (Adeleye, 2015).

Building on marginal lands was also considered a factor influencing flooding by $15.1 \%$ of the respondents. Although they are aware of the implications of siting buildings on marginal land, the residents of Suleja were of the opinion that affordability and availability of land influence their decision of building along the marginal lands. This claim is affirmed in Table 4. However, $22.7 \%$ of the respondents were of the opinion that building along river banks influences flood vulnerability in Suleja, an impression also shared by Environ (2017), an online platform. Environ (2017) was of the opinion that many of the victims of the 2017 flooding in Suleja were residents who lived in houses built along the river banks.

Table 4 explains the factors responsible for the purchase of land for building in Suleja. Affordability of land influenced the choice of land by $44.96 \%$ of the respondents. The respondents in this class care less about the location of their property. Relatively flat land was responsible for the choice of land by $32.37 \%$ of the respondents. Preference was given to property 
Table 3: Factors influencing flood vulnerability in Suleja

\begin{tabular}{|l|c|c|}
\hline \multicolumn{1}{|c|}{ Options } & Respondent & Percentage (\%) \\
\hline Indiscriminate waste disposal on water ways & 121 & 43.5 \\
\hline Poor drainage system & 50 & 18.0 \\
\hline Building on marginal lands & 42 & 15.1 \\
\hline Building along river banks & 63 & 22.7 \\
\hline Cultural belief & 2 & 0.7 \\
\hline Total & 278 & 100 \\
\hline
\end{tabular}

Source: Authors' field work

location by $15.47 \%$, while the availability of facilities influenced the choice of $7.19 \%$ of the respondents.

\subsection{Factors influencing the non- adherence of development control measures in Suleja}

A breakdown of official documents relating to the application and issuance of development permits was obtained from the Niger State Urban Development Board (NSUDB), Suleja Zonal Office. The information extracted from the documents revealed that five issues were responsible for the non-compliance of development control measures in Suleja. Results from an interview with an official of the Niger State Urban Development Board gave an insight into these factors.

Table 4: $\quad$ Factors responsible for physical development in Suleja

\begin{tabular}{|l|c|c|}
\hline \multicolumn{1}{|c|}{ Factors } & Respondents & $\begin{array}{c}\text { Percentage } \\
\text { (\%) }\end{array}$ \\
\hline Affordable land & 125 & 44.96 \\
\hline $\begin{array}{l}\text { Relatively flat } \\
\text { land }\end{array}$ & 90 & 32.37 \\
\hline Location & 43 & 15.47 \\
\hline $\begin{array}{l}\text { Availability of } \\
\text { facilities }\end{array}$ & 20 & 7.19 \\
\hline Total & 278 & 100 \\
\hline
\end{tabular}

Source: Authors' field survey

\subsubsection{Bureaucratic process in obtaining building approval}

The cumbersome process of seeking building approval often discourages developers from seeking building permits. Building permits in Suleja usually take longer. To seek a quick approval, the developers may have to follow some illegal processes. The technical and administrative procedure developers often pass through before their building permits is duly signed by the honourable commissioner usually refrain developers from seeking building approval.

\subsubsection{Laxity in inspection exercises by planning officials} the planning officials towards monitoring of ongoing physical development usually paves the way for illegal structures such as building along waterways, encroachment on marginal lands and access roads, because the monitoring of physical development is not done on a regular basis.

\subsubsection{Corruption and non- discipline by planning officials}

Buildings that ought to be marked for demolition are often spared because of the kickbacks received from the developers. According to the planning official interviewed, some building permits may not be released if the planning official responsible is not remunerated.

\subsubsection{Inadequate staff and use of obsolete equipment}

The Niger State Urban Development Board is faced with inadequate manpower. This factor can also be attributed to the laxity in the inspection of physical development in Suleja. The study revealed that the 10 political wards in Suleja do not have updated maps that can be used for charting ongoing physical development in the town. The cadastral maps available were prepared in the 1970s or the early 1980s. The use of obsolete maps has greatly affected the coordination of the proposed physical development in Suleja with the existing structures.
The lackadaisical attitude of

\subsubsection{Method of land ownership}

The study also revealed that the customary method of land ownership practised in Suleja has a negative impact on the physical planning. A large expanse of land is often sold by the locals without the preparation of layout plans. The inability of the locals and the "Mai-Anguwa" (community head) to produce a plan/ document to guide the proposed development is usually accompanied by numerous challenges. These challenges, according to the Niger State Urban Development Board, are poor delineation of boundaries by the locals which often encourages encroachment on other land uses by developers and the proliferation of slums in Suleja.

\subsection{Implication of non-adherence to development control measures in Suleja}

The study revealed that the emergence of slums, land degradation, flooding and poor accessibility are the effects of non-adherence to development control measures in Suleja. Table 5 reveals that $7.2 \%$ of the respondents were of the opinion that land degradation implies non-adherence to development control measures in Suleja. This category of respondents believed that the lands that ought to be conserved (buffer zones) are either converted or distorted, due to the laxity in development control measures. Poor accessibility and emergence of slum are attributed to the implication of non-adherence to development control measures by $12.6 \%$ and $46.0 \%$ of the respondents, respectively. The responses by the $46.0 \%$ of the respondents indicate that weakness in the enforcement of development control measures will lead to chaotic planning. Onwubiko (2017) also shared this belief and opined that houses in Suleja are mostly ramshackle, associated with congestion as if there is a total absence of town planning authority in Suleja. Onwubiko's (2017) statement indicates that development control measures are lacking. 
Table 5: Effects of non-adherence to development control measures in Suleja

\begin{tabular}{|l|c|c|}
\hline \multicolumn{1}{|c|}{ Option } & Respondents & $\begin{array}{c}\text { Percentage } \\
\text { (\%) }\end{array}$ \\
\hline $\begin{array}{l}\text { Land } \\
\text { degradation }\end{array}$ & 20 & 7.2 \\
\hline $\begin{array}{l}\text { Poor } \\
\text { accessibility }\end{array}$ & 35 & 12.6 \\
\hline $\begin{array}{l}\text { Emergence } \\
\text { of slum }\end{array}$ & 128 & 46.0 \\
\hline Flooding & 95 & 34.2 \\
\hline Total & 278 & 100 \\
\hline
\end{tabular}

Source: Authors' field work

On the other hand, $34.2 \%$ of the respondents (the second highest) were of the opinion that flooding is an implication of non-adherence to development control measures in Suleja. The responses of the $34.2 \%$ of the respondents who believed that flooding is an implication of non-adherence to development control measures can be attributed to the manner in which physical development is carried out. This claim was also affirmed by Opara (2017) who believed that the 90 houses destroyed and the 500 persons displaced in the course of the 2017 flooding in Suleja could have been avoided if development measures were strictly adhered to.

\section{CONCLUSION AND RECOMMENDATION}

In order to achieve an ideal city that will be attractive for living, working, and recreation, it is imperative to fully enforce the development control measures amidst the rapid urbanization experienced in Suleja. This study has effectively identified the buildings contravening development measures and the implications of non-adherence to development control measures.

The study recommends that buildings built in contravention of development control laws should be marked and demolished, as stipulated by the Town Planning Law of 1992. This Act will serve as a wake-up call to the public on the need to strictly adhere to development control measures.

The study also recommends that town planning officials should perform inspection exercises to development sites on a regular basis and that planners should be cautioned on the dangers of all forms of non-discipline. The bureaucracy involved in the building approval by the Niger State Urban Development Board (NSUDB) should be addressed by the Niger State government in order to have more plans approved as against the 35\% benchmark set by the Ministry. This will encourage developers to always seek development permits, thus reducing the rate of contravention.

The Niger State Environmental Protection Agency saddled with all environmental responsibilities should sensitize the residents of Suleja on the dangers of indiscriminate solid waste disposal, especially on waterways. This will go a long way in reducing flood vulnerability in the study area and elsewhere in the State. In addition, more skip bins and waste disposal facilities should be available and be properly sited by the Niger State Environmental Protection Agency (NSEPA) for effective waste collection and disposal.

\section{REFERENCES}

ACTIONAID. 2006. Climate change, urban flooding and the rights of the urban poor in Africa: Key findings from six African cities. A report of ActionAid International, October.

ADELEYE, B.M. 2015. Assessment of the consequences of urban growth in Suleja, Niger State (1987-2013). Unpublished Thesis (Masters). University of Ibadan, Nigeria, Department of Urban and Regional Planning.

ADETUNJI, M.A. \& OYELEYE, O.I. 2013. Evaluation of the causes and effects of flood in Apete, Ido Local Government Area, Oyo State, Nigeria. Journal of Civil and Environmental Research, 3(7), pp. 19-26.

ADGER, W.N. 2000. Social and ecological resilience: Are they related? Progress in Human Geography, 24(3), pp. 347-364. https://doi. org/10.1191/030913200701540465

ADGER, W.N. 2006. Vulnerability. Global Environmental Change, 16(3), pp. 268-281. https://doi.org/10.1016/j. gloenvcha.2006.02.006

AGBONKHESE, O., AGBONKHESE, E.G., AKA, E.O., JOE-ABAYA, J., OCHOLI, M. \& ADEKUNLE, A. 2014. Flood menace in Nigeria: Impacts, remedial and management strategies. Civil and Environmental Research, 6(4), pp. 32-40.

AHMED, A. \& DINYE, R.D. 2011. Urbanization and the challenges of development controls in Ghana: A case study of Wa Township. Journal of Sustainable Development in Africa, 13(7), pp. 210-235.

ALUKO, O. 2011. Development control in Lagos State: An assessment of public compliance to space standards for urban development. African Research Review, 5(5), pp. 167-184. https://doi. org/10.4314/afrrev.v5i5.14

ASHFIELD COUNCIL. 2015. Flood development control policy. Interim Development Assessment Policy. [online]. Available at: <www.ashfield.nsw. gov.au> [Accessed: 23 December 2017].

BHATTACHARYYA, G.K. \& JOHNSON, R.A 2014. Statistics: Principles and methods. $7^{\text {th }}$ edition. London, UK: John Wiley and sons Ltd.

BLAIKIE, P., CANNON, T., DAVIS, I. \& WISNER, B. 1994. At risk: Natural hazards, people's vulnerability and disasters. London: Routledge.

BWALA, H.B., OLADOSU, R.O. \& NGHALMI, S.M. 2016. The challenge of development control in Nigerian capital cities - A case of some selected cities in the Niger Delta. Developing Country Studies, 6(2), pp. 148-156.

CHEN, Y. 2004. An urban flooding treatment model based on GIS techniques. In: Webb, B., Acreman, M., Maksimovic, C., Smithers, H. \& Kirby, C. (Eds). Proceedings of the British Hydrological Society International Conference - Hydrology Science and Practice for the $21^{\text {st }}$ century, Imperial College London, July 2004. UK: BHS, pp. 361-364.

CRESWELL, J.W. 2014. Research design: Qualitative, quantitative and mixed methods approaches. $4^{\text {th }}$ edition. Thousand Oaks, CA: Sage.

CRESWELL, J.W. \& PLANO-CLARK, V.L. 2007. Designing and conducting mixed methods research. Thousand Oaks, CA: Sage. 
DAVOUDI, S. 2012. Resilience:

A bridging concept or a dead end? Planning Theory \&

Practice, 13(2), pp. 299-307.

10.1080/14649357.2012.677124

DOUGLAS, I., KOBOLD, M., LAWSON, N., PASCHE, E. \& WHITE, I. 2007. Characterisation of urban streams and urban flooding. In: Ashley, R., Garvin, S., Pasche, E., Vassilopoulos, A. \& Zevenbergen, C. (Eds). Advances in urban flood management. New York, NY: Taylor \& Francis, pp. 29-58. http://dx.doi. org/10.1201/9780203945988.ch3

DOUGLAS, I., ALAM, K., MAGHENDA, M., MCDONNELL, Y., MCLEAN, L. \& CAMPBELL, J. 2008. Unjust waters: Climate change, flooding and the urban poor in Africa. Environment and Urbanization, 20, pp. 187.205. https:// doi.org/10.1177/0956247808089156

EGUAROJE, O., ALAGA, T., OGBOLE, J., OMOLERE, S., ALWADOOD, J., KOLAWOLE, I. et al. 2015. Flood vulnerability assessment of Ibadan City, Oyo state, Nigeria. World Environment, 5, pp. 149-159.

ENVIRON. 2017. Flood wrecks havoc in Suleja, kills eight family members. [online]. Available at: <www. environnewsnigeria.com> [Accessed: 13 December 2017].

FGN (FEDERAL GOVERNMENT OF NIGERIA). 1992. Nigerian Urban and Regional Planning Decree 1992. Lagos: Federal Government Press.

GOODFELLOW, T. 2013. Planning and development regulation amid rapid urban growth: Explaining divergent trajectories in Africa. Geoforum, 48, pp. 83-93. https://doi.org/10.1016/j. geoforum.2013.04.007

GUIKEMA, S.D. 2009. Infrastructure design issues in disaster-prone regions. Science, 323(5919), pp. 302-1303. http://dx.doi.org/10.1126/ science. 1169057

GUNDERSON, L.H. 2010. Ecological and human community resilience in response to natural disasters. Ecology and Society, 15(2), p.18. https://doi. org/10.5751/ES-03381-150218

GWARY, D. 2008. Climate change, food security and Nigeria Agriculture. Paper presented at the workshop on the Challenges of Climate Change for Nigeria. NISER 19-20 May 2008.
HARTUNG, C., LERER, A., ANOKWA, Y., TSENG, C., BRUNETTE, W. \& BORRIELLO, G. 2010. Open data kit: Tools to build information services for developing regions. In: Proceedings of the $4^{\text {th }}$ ACM/ IEEE International Conference on Information and Communication Technologies and Development (ICTD '10) London, United Kingdom, December 13-16, ACM New York, NY Article No. 18. https://doi. org/10.1145/2369220.2369236

JUNAID, A.M. 2017. Housing for the Nigerian urban poor: A mirage or reality. An inaugural lecture delivered at the Federal University of Technology, Minna, 18 May.

KADI, A.S., HALINGALI, B.I. \& RAVISHANKAR, P. 2012. Problems of urbanization in developing countries: A case study in India. International Journal of Science and Nature, 3(1), pp. 93-104.

KIO-LAWSON, D., DURU, M.N., JOHN, B.D. \& EEBEE, A.L. 2016. The challenge of development control in Nigerian capital cities: A case of some selected cities in the Niger Delta. Developing Country Studies, 6(2), pp. 148-156.

LEKWOT, V.E., KYOM, B.C. \& BALASOM, M.K. 2013. The nature, scope and dimensions of development control, tools and machineries in urban planning in Nigeria. International Journal of Innovative Environmental Studies Research, 1(1), pp. 48-54.

LIAO, K.H. 2012. A theory on urban resilience to floods - A basis for alternative planning practices. Ecology and Society, 17(4), article 48. https:// doi.org/10.5751/ES-05231-170448

LUERS, A., LOBELL, D., SKLAR, L., ADDAMS, C. \& MATSON, P. 2003. A method for quantifying vulnerability, applied to the agricultural system of the Yakie Valley, Mexico. Global Environmental Change, 13, pp. 255-267. https://doi.org/10.1016/ S0959-3780(03)00054-2

MABOGUNJE, A.L. 1990. Urban planning and the post-colonial state in Africa: A research overview. African Studies Review, 33(2), pp. 121-203. https://doi.org/10.2307/524471
MARRICKVILLE COUNCIL. 2015.

Policy for identifying properties subject to flood related development controls. [online]. Available at: <www. marrickville.nsw.gov.au> [Accessed: 23 December 2017].

MCASLAN, A. 2010. The concept of resilience: Understanding its origin, meaning and utility. Adelaide, Australia: Torrens Resilience Institute.

MEEROW, S., NEWELL, P.N. \& STULTS, M. 2016. Defining urban resilience: A review. Landscape and Urban Planning, 147(2016), pp. 38-49. https://doi.org/10.1016/j. landurbplan.2015.11.011

MULLER, A.M., REITER, J. \& WEILAND, U. 2017. Assessment of urban vulnerability towards floods using an indicator-based approach: A case study for Santiago de Chile. Natural Hazards and Earth System Science, 11, pp. 2107-2123. https://doi.org/10.5194/ nhess-11-2107-2011

NELSON, S. 2001. River systems and causes of flooding. Geology 204 Tulane University. [online]. Available at: <www.tulane.edu/sanelson/ geo/204/subsidence. pdf> [Accessed: 23 October 2011].

NEUMAN, W.L. 1991. Social research methods: Quantitative and qualitative approaches. $2^{\text {nd }}$ edition. London: Allyn \& Bacon.

NKWUNONWO, U.C. 2016. A review of flooding and flood risk reduction in Nigeria. Global Journal of Human-Social Science B: Geography, Geo-Sciences, Environmental Science and Disaster Management, 16(2), pp. 22-42.

(NPC) NATIONAL POPULATION COMMISSION NPC, 2006 . Priority tables. [online]. Available at: <population.gov.ng> [Accessed: 10 October 2017].

OBABORI, A.O., OBIUWEVBI, D.A. \& OLOMU, J.I. 2007. Development control an important regulator of settlement growth: A case study of Ekpoma, Nigeria. Journal of Human Ecology, 21(4), pp. 285-291.

ODUFUWA B.O., ADEDEJI, O.H., OLADESU, J.O. \& BONGWA, A. 2012. Floods of fury in Nigerian cities. Journal of Sustainable Development, 5(7), pp. 69-79. 
ODUNUGA, S., OYEBANDE, L. \&

OMOJOLA, A.S. 2012. Social-economic indicators and public perception on urban flooding in Lagos, Nigeria. Hydrology for Disaster Management: Special Publication of the Nigerian Association of Hydrological Sciences. Abuja, Nigeria: NAHS, pp. 82-96.

OGUNDELE, F.O., AYO, O., ODEWUMI, S.G. \& AIGBE, G.O. 2011. Challenges and prospects of physical development control: A case study of Festac Town, Lagos, Nigeria. African Journal of Political Science and International Relations, 5(4), pp. 174-178.

OGUNSESAN, D.K. 2004. The process and problems of development control and some remedial solutions. The Environscope: A Multidisciplinary Journal, 1(1), pp. 50-56.

OKORIE, G. 2015. Urbanization problems in developing countries. [online]. Available at: <https://www. linkedin.com/pulse/ urbanizationproblems-in-developing-countries> [Accessed: 13 December 2017].

OLA, A. 2011. Development control in Lagos State: An assessment of public compliance to space standards for urban development. International Multidisciplinary Journal, Ethiopia, 5(5), pp. 169-184.

OLOTUAH, A.O. \& ADESIJI, O.S. 2005. Housing poverty, slum formation and deviant behaviour. Federal University of Technology, Akure, Nigeria and 61 Glimpsing Green, Erith Kent, DA 18 4HB London.

OMOLE, F.K. 2012. Land development and planning laws in Nigeria: The historical account. Journal of Law, Policy and Globalization, 8, pp. 25-31.

ONWUBIKO, E. 2017. The Lagos/ Suleja flood. [online]. Available at: <www.sunnewsonline.com> [Accessed: 13 December 2017].

OPARA, E. 2017. Suleja flood: Death toll rises to 13. NSEMA recovers eight bodies. [online]. Available at: <https:// punchng.com> [Accessed: 4 April 2018].

OYELEYE, O.O. 2013. Challenges of urbanization and urban growth in Nigeria. American Journal of Sustainable Cities and Society, 2(1), pp. 79-95.

PELLING, M. 1997. What determines vulnerability to floods: A case study in Georgetown, Guyana. Environment and Urbanization, 9(1), pp. 203-226.
POTSCHIN, M. 2009. Land use and the state of the natural environment. Land Use Policy, 26S, pp. 170177. http://dx.doi.org/10.1016/j. landusepol.2009.08.008

SALAMI, R.O., VON MEDING, J.K. \& GIGGINS, H. 2017. Urban settlements' vulnerability to flood risks in African cities: A conceptual framework. Jàmbá: Journal of Disaster Risk Studies, 9(1), article 370. https://doi.org/10.4102/ jamba.v9i1.370

SATAKE, E.B. 2016. Basic statistical tools in research and data analysis. Indian Journal of Anesthesia, 60(9), pp. 662-669.

SATTERTHWAITE, D., HUQ, S., PELLING, M., REID, H. \& ROMERO LANKAO, P. 2007. Human settlements discussion paper series theme: Climate change and cities - 1: Adapting to climate change in urban areas. The possibilities and constraints in lowand middle-income nations. [online]. Available at: <http://www.rockfound.org/ initiatives/climate/climate_change.html> [Accessed: 20 December 2017].

SOURCEFORGE. 2019. Terra incognita. [online]. Available at: <https:// sourceforge.net/projects/terraincognita2/> [Accessed: 19 March 2019].

UN-HABITAT. 2003. The challenge of slums: Global report on human settlements. Revised and updated version (April 2010). [online]. Available at: <www.unhabitat.org/grhs/2003> [Accessed: 10 April 2019].

\section{UNITED NATIONS INTERNATIONAL} STRATEGY FOR DISASTER REDUCTION, 2015. Poorly planned and managed urban development. [Online] Available at: <https://www.preventionweb. net> [Accessed: 9 April 2019].

UN-WATER. 2011. Cities coping with water uncertainties. Media Brief, UN-Water Decade Programme on Advocacy and Communication.

WALKER, B. \& WESTLEY, F. 2011. Perspectives on resilience to disasters across sectors and cultures. Ecology and Society, 16(2), p. 4. https://doi. org/10.5751/ES-04070-160204

WALKER, B., HOLLING, C.S., CARPENTER, S.R. \& KINZIG, A. 2004. Resilience, adaptability and transformability in social-ecological systems. Ecology and Society, 9(2), p. 5. https://doi.org/10.5751/ES-00650-090205
WARAMI, U. 2017. Flood renders many homeless in Suleja. Vanguard, 9 July [Online] Available at: <https:// www.vanguardngr.com/2017/07/ flood-renders-many-homeless-suleja/> [Accessed: 9 April 2019].

WISNER, B., BLAIKIE, P., CANNON, T. \& DAVIS, I. 2004. At risk. London: Routledge

WOLTJER, J. \& VAN DEN BRINK, M. 2015. A strategy-based framework for assessing the flood resilience of cities - A Hamburg case study. Planning Theory \& Practice, 16(1), pp. 45-62. http://dx.doi.org/10.1080/14649357.201 4.1000950

YEMI, O. 2004. Problems and prospect of development control. Paper presented at the 2004 Annual Delegates Conference of the Nigerian Bar Association Holding at the International Conference Centre, Abuja, 22-27 August 2004. 